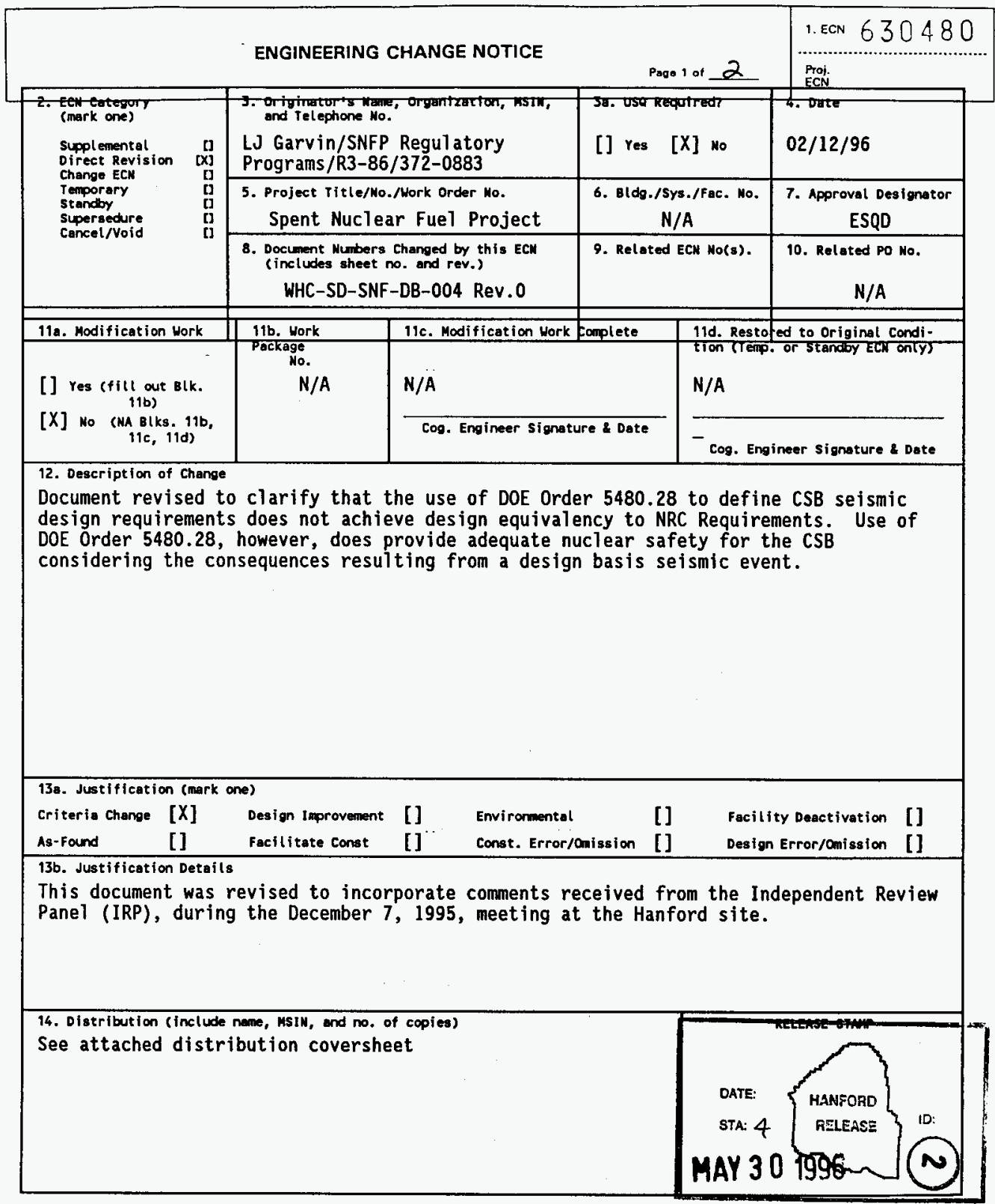




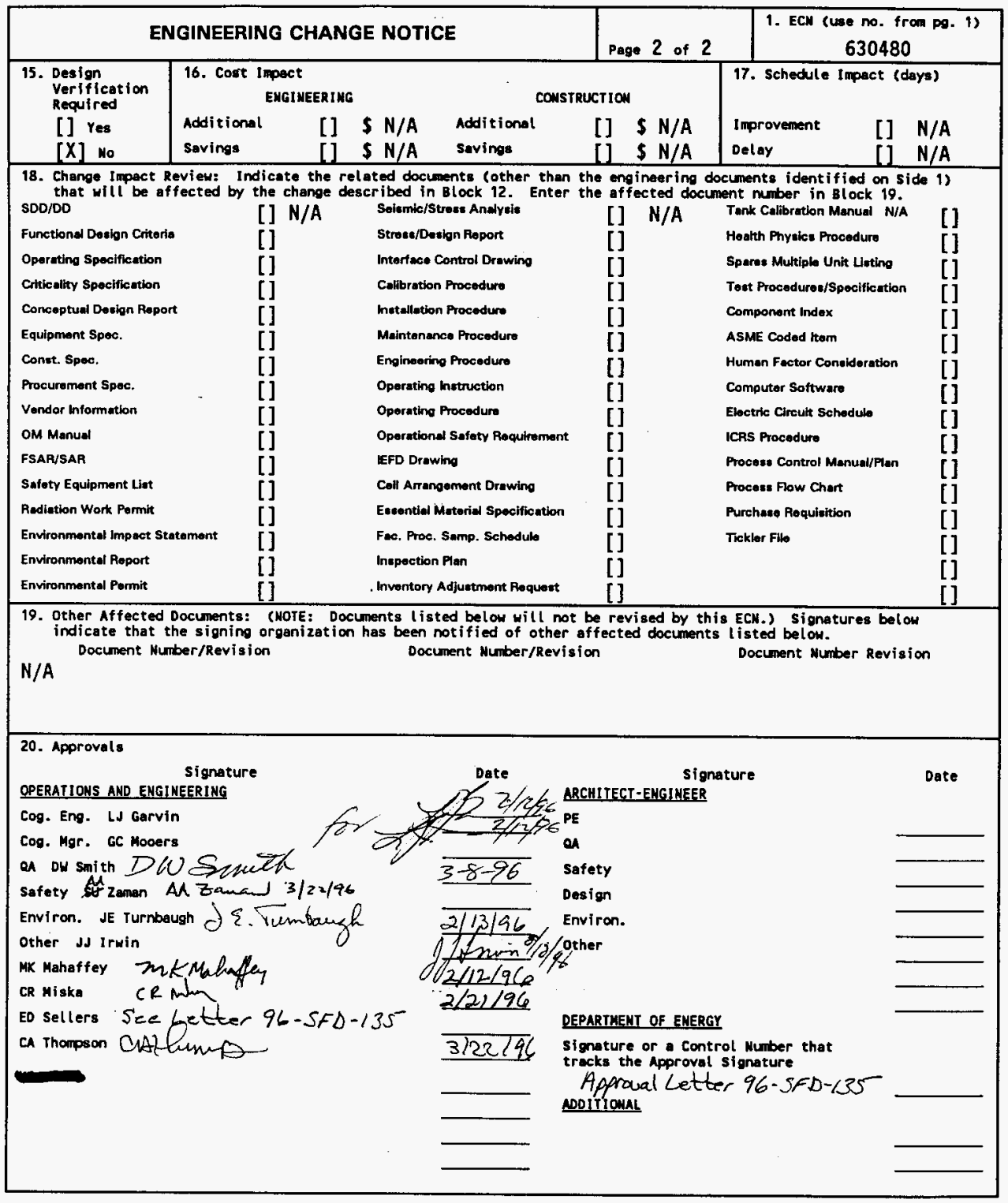




\title{
Spent Nuclear Fuel Project Seismic Design Criteria, NRC Equivalency Evaluation Report
}

\author{
L. J. Garvin \\ Westinghouse Hanford Company, Richland, WA 99352 \\ U.S. Department of Energy Contract DE-ACO6-87RL10930 \\ ECN 630480 \\ EDT/ECN: 630478- ens C UC: 510 \\ Org Code: 5V400 5/30/96 Charge Code: F93DL1 \\ B\&R Code: EW3135040 Total Pages: 34 Ems \\ $5 / 30 / 96$ \\ Key Words: Seismic, NRC, Performance Category, Safety Equivalency \\ Abstract:
}

TRADEMARK DISCLAIMER. Reference herein to any specific conmercial product, process, or service by trade name, trodemark, marufacturer, or otherwise, does not necessarily constitute or imply its endorsement, recomnendation, or favoring by the United states Government or any agency thereof or its contractors or subcontractors.

Printed in the United States of America. To obtain copies of this document, contact: HHC/BCS Document Control Services, P.O. Box 1970, Mailstop H6-08, Richland WA 99352, Phone (509) 372-2420; Fax (509) 376-4989.
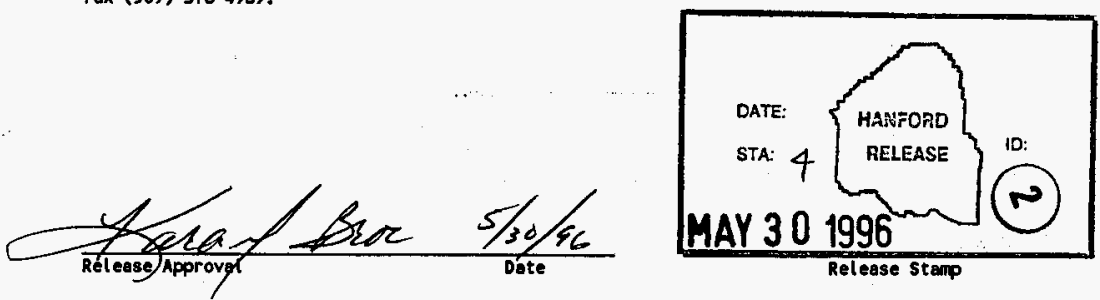
RECORD OF REVISION

\begin{tabular}{l|r} 
(1) Dociment Number & । \\
WHC-SD-SNF-DB-004 & Page \\
\hline
\end{tabular}

(2) ritle

Spent Nuclear Fuel Project Seismic Design Criteria, NRC Equivalency Evaluation Report CHANGE CONTROL RECORD

\begin{tabular}{|c|c|c|c|c|}
\hline \multirow{2}{*}{ (3) Reyision } & \multirow{2}{*}{\multicolumn{2}{|c|}{$\begin{array}{l}\text { (4) Description of Change - Replace, Add, and Delete Pages } \\
E D T=6,2977 \text {, }\end{array}$}} & \multicolumn{2}{|c|}{ Authorized for Release } \\
\hline & & & (5) Cog. Engr. & (6) Con. Mor. \\
\hline 1 RS & (7) & $\begin{array}{l}\text { Document revised to clarify that the } \\
\text { use of DOE Order } 5480.28 \text { to define CSB } \\
\text { seismic design requirements does not } \\
\text { achieve design equivalency to NRC } \\
\text { Requirements. ECN- } 630480\end{array}$ & $y 2$ & $3 \times 2,1 / 2$ \\
\hline & & & & \\
\hline & & & & \\
\hline & & & & \\
\hline & & & & \\
\hline & & & & \\
\hline & & & & \\
\hline & & & & \\
\hline & & & & \\
\hline & & & & \\
\hline & & & & \\
\hline & & & & \\
\hline & & & & \\
\hline & & & & \\
\hline & & & & \\
\hline & & & & \\
\hline & & & & \\
\hline & & & & \\
\hline & & & & \\
\hline & & & & \\
\hline & & & & \\
\hline & & & & \\
\hline & & & & \\
\hline & & & & \\
\hline & & & & \\
\hline & & & & \\
\hline & & & & \\
\hline & & & & \\
\hline & & & & \\
\hline & & & & \\
\hline 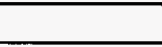 & & & & \\
\hline
\end{tabular}




\section{SPENT NUCLEAR FUEL PROJECT SEISMIC DESIGN CRITERIA}

\section{NUCLEAR REGULATORY COMMISSION EQUIVALENCY EVALUATION REPORT}

December 1995

Prepared for the U.S. Department of Energy

Spent Nuclear Fuels Division

Westinghouse Hanford Company

P.O. Box 1970

Richland, Washington 99352 
EXECUTIVE SUMMARY $\ldots \ldots \ldots \ldots \ldots \ldots \ldots \ldots \ldots \ldots \ldots \ldots \ldots \ldots \ldots$

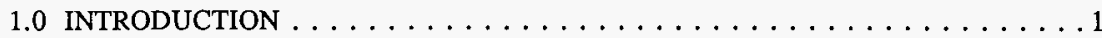

2.0 DOE AND NRC SEISMIC DESIGN CRITERIA $\ldots \ldots \ldots \ldots \ldots \ldots \ldots$

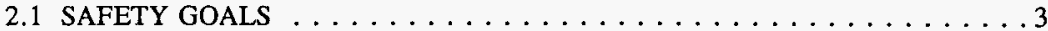

2.2 NRC SEISMIC DESIGN CRITERIA $\ldots \ldots \ldots \ldots \ldots \ldots \ldots \ldots$

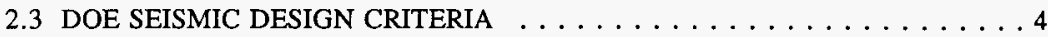

2.4 COMPARISON OF NRC AND DOE SEISMIC DESIGN METHODOLOGIES . 5

3.0 APPLICATION OF SEISMIC DESIGN CRITERIA TO THE CANISTER STORAGE

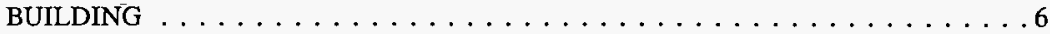

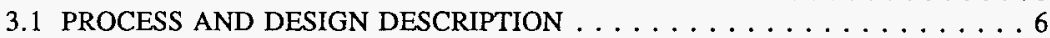

3.2 PRELIMINARY SAFETY ANALYSES $\ldots \ldots \ldots \ldots \ldots \ldots \ldots$

3.3 SAFETY CLASS AND PERFORMANCE CATEGORY CORRELATION . . . 10

4.0200 EAST AREA CSB SITE SEISMIC RESPONSE . . . . . . . . . . 11

4.1 PERFORMANCE CATEGORY 3 SEISMIC DESIGN RESPONSE SPECTRA . 11

4.2 NRC APPENDIX A-TYPE GROUND MOTION . . . . . . . . . 11

4.3 CURRENT CANISTER STORAGE BUILDING SEISMIC DESIGN . . . . . 12

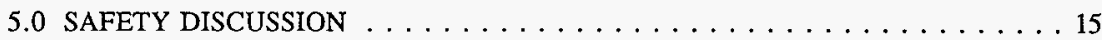

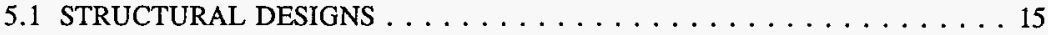

5.2 SEISMIC SAFETY RISKS . . . . . . . . . . . . . . . 15

5.3 QUALITATIVE EFFECTS FROM AN NRC DESIGN EARTHQUAKE $\ldots . .18$

5.4 SNF PROJECT CONSIDERATIONS . . . . . . . . . . . . . . . . 19

5.5 SELECTION OF SNF PROJECT SEISMIC DESIGN CRITERIA . . . . . . 20

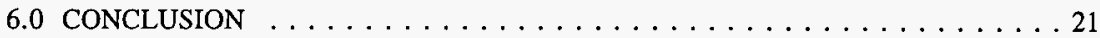

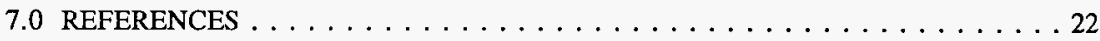

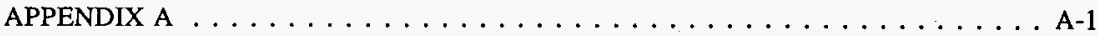




\section{LIST OF TABLES}

1. Accident Analyses Results . . . . . . . . . . . . . . . 8

2. Conservative Analyses Results $\ldots \ldots \ldots \ldots \ldots \ldots \ldots \ldots \ldots$

3. Comparison of Important Safety Items $\ldots \ldots \ldots \ldots \ldots \ldots \ldots \ldots$

A-1. Comparison of Mean Annual Seismic-Induced Core Damage Frequencies From Past Reactor Probabilistic Risk Assessments . . . . . . . . . . . . . A-1

A-2. Comparison of Natural Phenomena Hazards Performance Goals and Performance Categories . . . . . . . . . . . . . . . . . . A-1

\section{LIST OF FIGURES}

1. Horizontal Response Spectra for the 200 Area Canister Storage Building Site . . 13

2. Vertical Response Spectra for the 200 Area Canister Storage Building Site . . . . 14 
ACRONYMS \& ABBREVIATIONS

CFR Code of Federal Regulations

CSB Canister Storage Building

DBE Design Basis Earthquake

DOE U.S. Department of Energy

FR Federal Register

HWVP Hanford Waste Vitrification Project

HVAC Heating, Ventilation, and Air Conditioning

ISFSI Independent Spent Fuel Storage Installation

MCO Multi-Canister Overpack

MEI Maximum Exposed Individual

NPH Natural Phenomena Hazards

NRC U.S. Nuclear Regulatory Commission

PC Performance Category

PRA Probabilistic Risk Assessment

PSE Preliminary Safety Evaluation

SC Safety Class

SNF Spent Nuclear Fuel

SSE Safe Shutdown Earthquake 


\section{EXECUTIVE SUMMARY}

The U.S. Department of Energy (DOE) established the K Basins Spent Nuclear Fuel Project (SNF Project) to address safety and environmental concerns associated with deteriorating spent nuclear fuel presently stored in the $\mathrm{K}$ Basins at the Hanford site. The project plans are to retrieve the fuel from the $\mathrm{K}$ Basins, stabilize the fuel with conditioning processes, and store the fuel in the 200 Area of the Hanford site until a suitable long-term repository is established.

The DOE, commissioned under the Atomic Energy Act of 1954, has legal responsibility to conduct operations at its defense nuclear facilities in a safe and environmentally sound manner. Recognizing this responsibility, the DOE has established a rigid set of orders, standards, and requirements. In addition, DOE has initiated a policy in K Basins Spent Nuclear Fuel Project - Regulatory Policy (DOE 1995) that requires the new processes and facilities constructed to condition and store $\mathrm{K}$ Basins fuel be designed to achieve a level of nuclear safety comparable to that of U.S. Nuclear Regulatory Commission (NRC) licensed facilities. This is accomplished by supplementing existing DOE orders and requirements with appropriate NRC regulations. The overlaying DOE guidance for this policy is to assure that the policy is implemented in a cost-effective manner.

The SNF Project has compared NRC regulations [Title 10, Code of Federal Regulations (CFR), parts 0-199] to DOE orders and requirements to identify areas where the NRC regulations should be applied. After comparing the DOE and NRC seismic design requirements, the SNF Project has determined that seismic designs will be based on DOE Order 5480.28, Natural Phenomena Hazards Mitigation, and its implementing standards, in lieu of the NRC requirements. This decision is based on the fact that: DOE Order 5480.28 and its implementing standards provide technically defensible seismic design criteria which assures adequate protection for the public, the worker, and the environment; and the application of the NRC requirements would not be cost effective as it would result in significant cost and schedule impact to the SNF Project with only a limited reduction of nuclear safety risk. Based on these considerations, it was concluded that the public interest would be best served by the use of DOE Order 5480.28 and its implementing standards in lieu of NRC requirements. It is further concluded that this decision is consistent with DOE guidance for implementation of the K Basin Spent. Nuclear Fuel Project Regulatory Policy.

This paper provides the basis for the SNF Project's decision and justification that designs developed using the criteria of DOE Order 5480.28 and the resulting PC-3 performance category provide adequate safety based on a responsible, technically defensible, and cost-effective implementation of seismic design safety for new SNF Project processes and facilities. The key arguments that support this conclusion are summarized in the sections that follow. 


\section{NUCLEAR SAFETY}

Application of seismic design criteria based on DOE Order 5480.28, Natural Phenomena Hazards Mitigation and its implementing standards, ensures an adequate level of safety protection against potential seismic events that could occur at Hanford's spent nuclear fuel facilities. Considering seismic safety risks, the designs produced using the Order's Performance Category (PC) 3 criteria' (proposed for new SNF Project processes and facilities) provide a level of nuclear safety comparable to that of licensed nuclear power plants in the United States.

Use of the PC-3 seismic performance criteria for a fuel storage facility [e.g., the Canister Storage Building (CSB)] located in the Hanford 200 Area results in seismic safety risks that are estimated to be about one order of magnitude (i.e., a factor ranging from 3 to 50) lower than the seismically induced risks from typical licensed nuclear power plants in the United States (see Section 5.1 of this report). Potential consequences associated with seismically induced accidents from a fuel storage facility (e.g., the CSB) are estimated to be at least 2 orders of magnitude less severe than those from a power reactor facility, due to the lower quantity of radionuclides present in the storage facility. Although these figures represent an estimated range of risk and are not precise in nature, they demonstrate that design to the DOE criteria provides an acceptable level of nuclear safety and a degree of protection against seismic events that is equivalent to or better than that provided for NRClicensed commercial nuclear power reactors.

\section{NRC EQUIVALENCE}

DOE's Regulatory Policy for the Spent Nuclear Fuel Project (DOE 1995) states “. . . the K Basin Spent Nuclear Fuel Project will achieve nuclear safety equivalency to comparable Nuclear Regulatory Commission licensed facilities.” The policy objectives are:

- "to achieve a set of requirements that are technically defensible and cost-effective,

- to achieve in the design and construction of new SNF Project facilities, a level of nuclear safety comparable to that of NRC-licensed commercial nuclear facilities, and

- to enhance public understanding and confidence in the safety of new facilities by following an enhanced regulatory strategy."

Comparing NRC and DOE seismic design criteria as they apply to a fuel storage facility (e.g., the CSB) reveals that the designs developed under the NRC deterministic

\footnotetext{
${ }^{1}$ Seismic performance categories are defined in DOE Order 5480.28 based on performance goals established in that Order and associated implementation standards. For facilities in the Hanford 200 Area East, a PC-3 seismic performance category results in a conservative acceleration response spectra anchored at a peak horizontal value of about $0.2 \mathrm{~g}$ (i.e., a $0.2 \mathrm{~g}$ response spectra).
} 
methods for specifying seismic response spectra results in seismic design criteria that are more conservative than DOE requirements would prescribe. The DOE seismic design requirements are based on the application of a graded approach that is dependent upon the hazards present in a facility and a probabilistic assessment of the likelihood of future seismic occurrence.

The NRC seismic design requirements for a fuel storage facility are the same as NRC seismic design requirements for a nuclear power reactor facility. The DOE and NRC requirements would prescribe nearly equivalent designs for a nuclear power reactor. However, for a fuel storage facility, the DOE criteria prescribes less stringent seismic design loads due to the facility's lower hazard potential. Thus, use of the DOE Order 5480.28 seismic design criteria would not produce designs equivalent to those developed under the NRC seismic design criteria.

The NRC approach (10 CFR 72.120) requires use of 10 CFR 100, Appendix A, Seismic and Geologic Siting Criteria for Nuclear Power Plants. Application of 10 CFR 100, Appendix A criteria for nuclear power reactors will result in a higher level design earthquake but will not significantly increase the level of public safety. Examination of the history of application of seismic design requirements to fuel storage facilities suggests that the NRC has considered selection of the design-basis seismic event based on the potential consequences of seismically induced accidents (see Section 2.2 of this report). At this point in time, however, the NRC regulations do not formally recognize a risk based graded approach in its application of criteria for selection of the design basis earthquake for a spent fuel storage facility.

The application of DOE's graded approach in DOE Order 5480.28 results in designs that are safe and technically defensible. Considering the added benefits that the application of DOE's graded approach to nuclear safety establishes for the SNF Project in terms of risk, cost, and schedule - the SNF Project recommends continued use of DOE Order 5480.28 seismic design criteria. Based on the above considerations, DOE's Regulatory Policy and its underlying objectives can be satisfied through the use of DOE Order 5480.28.

\section{EVALUATION OF THE EXISTING CANISTER STORAGE BUILDING DESIGN}

Completion of the partially constructed Canister Storage Building results in significant cost and schedule benefits for the SNF Project. The existing CSB was designed to a horizontal seismic spectra anchored at $0.35 \mathrm{~g}$ in anticipation of the draft guidance on seismic design requirements at the time. The existing CSB seismic design is conservatively designed as compared to the design for a PC-3 facility.

An assessment of earthquake damage to the current CSB design was conducted for a seismic event with a response spectra anchored at $0.52 \mathrm{~g}$ (1.5 times greater than the current $0.35 \mathrm{~g}$ design basis response spectra and 2.6 times the $0.2 \mathrm{~g}$ PC- 3 response spectra). This event is slightly larger than the estimated 10 CFR 100 , Appendix A response spectra (i.e., $0.49 \mathrm{~g}$ response spectra) for the Hanford 200 East Area. The results of this assessment 
indicate a less than $10 \%$ probability of unacceptable performance of the CSB structures, systems, and components for this larger earthquake. The assessment results indicate that the existing CSB design provides an adequate level of safety, considering the design conservatism built into the CSB through implementation of DOE design requirements.

\section{PROJECT CONSIDERATIONS}

The impact to the SNF Project of using the 10 CFR 100, Appendix A nuclear reactor seismic design criteria for design of the CSB, is estimated to cost an additional $\$ 29$ million and result in an approximate six-month delay in the project schedule. Upgrading the CSB or other new SNF Project facilities to the 10 CFR 100, Appendix A $(0.49 \mathrm{~g})$ response spectra is not required to achieve an adequate level of safety, and incremental seismic risk improvement is small. Thus, redesign of the CSB for improved seismic response capabilities (and the associated construction upgrades) are not cost effective and do not support the urgent safety considerations requiring the expedited removal of the fuel from the $\mathrm{K}$ Basins.

The present storage of the spent fuel in the $\mathrm{K}$ Basins presents a significant safety and environmental risk (Bergsman 1995), including risks from seismic events as well as all other accident initiators. Once the fuel is removed from $\mathrm{K}$ Basins into the CSB or a similar facility in the 200 Area: (1) it will no longer present a threat to the Columbia River, (2) the fuel will have been dried to prevent continued corrosion, which produces radioactive particulate that can potentially be spread following any release, and (3) it will be doubly contained to provide increased protection against release to the environment. Delaying removal of fuel from the $\mathrm{K}$ Basins by six months (which is the projected schedule delay required to upgrade the CSB design to accommodate a $0.49 \mathrm{~g}$ response spectra) would unnecessarily extend risks associated with $\mathrm{K}$ Basins operation for a longer period of time and would tend to reduce the small risk benefit achieved by redesigning the CSB for larger earthquakes.

\section{CONCLUSION}

This paper demonstrates that the application of DOE Order 5480.28 provides adequate safety and a responsible, technically defensible, and cost-effective implementation of seismic design safety for SNF Project processes and facilities that is consistent with DOE's Regulatory Policy. The requirements specified in the DOE Order 5480.28 criteria achieve designs that are not the same as that of comparable NRC facilities; however, considering seismic safety risks, these designs provide a level of nuclear safety comparable to facilities designed using the NRC requirements. Furthermore, the use of DOE's graded approach applied to the seismic design criteria significantly minimizes the risk, cost, and schedule of the SNF Project and supports the need for expediting fuel removal away from the Columbia River in response to DOE, public, and stakeholder concerns. The SNF Project recommends that the DOE Order 5480.28 seismic design criteria for a PC-3 performance category be applied to new SNF Project processes and facilities. 
The current design criteria of the CSB, using a more conservative response spectra (0.35g), provides an even greater level of safety than that provided by the use of a PC-3 response spectra for the SNF Project. The SNF Project further recommends that the CSB design be continued using the $0.35 \mathrm{~g}$ response spectra. 
SPENT NUCLEAR FUEL PROJECT

SEISMIC DESIGN CRITERIA -

NUCLEAR REGULATORY COMMISSION

EQUIVALENCY EVALUATION REPORT

\subsection{INTRODUCTION}

The DOE has established the Spent Nuclear Fuel Project (SNF Project) to expeditiously move the spent nuclear fuel from the $\mathbf{K}$ Basins to a new storage facility located in the 200 East Area of the Hanford site. The present storage of spent nuclear fuel in the K Basins, which are located near the Columbia River, presents significant environmental, worker, and public health risks (Bergsman 1995). The intent of the SNF Project is to move the fuel into a new facility for temporary storage away from the Columbia River as soon as possible, significantly reducing the environmental and safety risks. The new facility will provide interim, safe storage of the spent nuclear fuel until a suitable long-term repository is established.

Recommendations for a series of aggressive projects to construct and operate systems and facilities to manage the safe removal of $\mathrm{K}$ Basins fuel were made in the Hanford Spent Nuclear Fuel Recommended Path Forward (WHC 1994) and its subsequent update, Hanford Spent Nuclear Fuel Project Integrated Process Strategy for K Basins Fuel (WHC 1995a). The recommendations call for the construction of a Canister Storage Building (CSB) in the 200 area of the Hanford site to serve as the interim storage location for $\mathrm{K}$ Basins fuel. Additionally, the Integrated Process Strategy recommends use of a two-step fuel drying and conditioning process to mitigate fuel degradation problems and to assure safe storage of the fuel. The two-step process consists of vacuum drying the fuel as it is removed from the basins (prior to its repackaging for transport to the 200 area) and then, hot-vacuum conditioning the fuel in a facility near the CSB prior to interim storage.

The DOE established a policy in K Basins Spent Nuclear Fuel Project - Regulatory Policy (DOE 1995; hereafter referred to as the Regulatory Policy) that new SNF Project processes and facilities achieve nuclear safety equivalence to comparable Nuclear Regulatory Commission (NRC) licensed facilities. The policy will be accomplished by applying technical requirements to SNF Project facilities based on those applied by the NRC to comparable licensed facilities. This will be accomplished within the bounds of the DOE's objectives that the facility requirements remain technically defensible and cost-effective.

This paper considers the seismic design criteria to be applied to the SNF Project facilities with regard to the equivalency requirements described in the Regulatory Policy. The SNF Project is proposing the use of the DOE seismic design criteria established in DOE Order 5480.28, Natural Phenomena Hazards Mitigation. In the following discussion, the CSB is used as an example case application of the DOE and NRC seismic design criteria to compare resulting designs, seismic risks, costs, and other considerations developed by these 
methods. The results demonstrate that the DOE criteria provide a design that is safe, cost effective, and consistent with the intent of DOE's Regulatory Policy. 


\subsection{DOE AND NRC SEISMIC DESIGN CRITERIA}

This section describes the DOE and NRC methods for determining seismic design criteria for spent nuclear fuel storage facilities. Although the DOE and NRC seismic design criteria are developed differently, the methodologies share the same basic objective-to provide an adequate level of safety for protection against seismic events that is consistent with safety goals and policies.

\subsection{SAFETY GOALS}

Evaluation of the DOE's and the NRC's nuclear safety policies indicates that the two policies are essentially the same. Both safety policies require that the general public be protected such that no individual bears significant additional risk to health and safety from the operation of a nuclear facility above the risks to which members of the general population are normally exposed. Both safety policies quantify the risk by requiring that the risk to an average individual in the vicinity of a facility should not exceed one-tenth of one percent $(0.1 \%)$ of the risks (both prompt and latent) to which members of the population are generally exposed. Safety goals are used by the DOE and NRC primarily as guidelines for managing the overall risks of the facilities associated with nuclear activities. The actual safety impacts of nuclear facilities is managed through implementation of specific design criteria found in applicable agency regulations and standards.

\subsection{NRC SEISMIC DESIGN CRITERIA}

The NRC requirements for licensing spent nuclear fuel storage facilities, including requirements for seismological siting criteria, are documented in Title 10 Code of Federal Regulations (CFR), Part 72, Licensing Requirements for the Independent Storage of Spent Nuclear Fuel and High-Level Radioactive Waste. The regulations define an independent spent fuel storage installation (ISFSI) as a complex designed and constructed for the interim storage of spent nuclear fuel. Section 102 of 10 CFR 72 requires that ISFSIs sited "West of the Rocky Mountain Front (west of approximately $104^{\circ}$ west longitude), and in other areas of known potential seismic activity, seismicity will be evaluated by the techniques of Appendix A of part 100 of this chapter." This section also requires "For sites that have been evaluated under the criteria of Appendix A of 10 CFR 100, the design earthquake must be equivalent to the safe shutdown earthquake for a nuclear power plant."

Appendix A of $10 \mathrm{CFR}$ 100, Seismic and Geologic Siting Criteria for Nuclear Power Plants, establishes a deterministic approach that identifies the maximum earthquake potential at a site considering the regional and local geology and seismology. This earthquake is designated the "Safe Shutdown Earthquake," or SSE, which is the earthquake that produces the maximum vibratory ground motion for which certain structures, systems, and components of a nuclear power plant are designed to remain functional. The SSE is equivalently designated the "Design Basis Earthquake (DBE)." 
ISFSIs were licensed by the NRC under the general regulation for Domestic Licensing of Special Nuclear Material, 10 CFR 70, prior to November 1980. Early siting guidelines for wet pool storage of spent fuel recognized the fact that the radiological inventory at risk in an ISFSI is some four orders of magnitude less than that in a power reactor, and that there are few energy sources available to disperse the inventory during design basis accidents. Thus, the NRC practice for development of siting requirements for these facilities was different from the requirements developed for power reactors.

During the latter part of the 1970s, there was considerable effort being made at the NRC to develop regulations for the back end of the nuclear fuel cycle to allow final disposal of high-level nuclear waste. It was decided at that time to develop a new part of the regulations to specifically address the licensing requirements for storage of spent fuel in an independent spent fuel storage installation. The final rule in 10 CFR 72, was issued in November 1980 (46 FR 74693). An examination of the rule-making record during the proposed issuance of 10 CFR 72 indicates that the NRC was considering application of graded seismic requirements based on the hazards present in a facility, which is similar to DOE criteria (Bernero 1995). In the final rule-making, however, the NRC could not reach a consensus on the methodology for implementing graded requirements. Consequently, the NRC adopted the seismic requirements of Part 100, Appendix A, for ISFSIs. However, the NRC has not specified the structural design rules to be applied for ISFSIs. Therefore, a direct comparison with a comparable NRC licensed facility is not possible.

\subsection{DOE SEISMIC DESIGN CRITERIA}

The DOE seismic design requirement for nuclear facilities is provided in DOE Order 5480.28, Natural Phenomena Hazards Mitigation. The DOE Order, along with its implementing standards, uses a graded approach in applying seismic design criteria. Structures, systems, and components of a facility are assigned one of five performance categories in accordance with the guidance provided in DOE-STD-1021-92, Natural Phenomena Hazards Performance Categorization Criteria for Structures, Systems, and Components (DOE 1992). The performance categories provide a graded application of seismic design criteria for selecting the DBE and structural design rules based on consideration of the relative probabilities and consequences of potential damage or failure of a facility.

Each performance category has an associated natural phenomena hazards (NPH) performance goal with a mean annual probability of exceedance of acceptable behavior limits. The NPH performance goal is a measure of the level of protection against potential seismic events and is used as a target for the establishment of seismic mitigation design requirements.

Performance goals required for seismic events relative to defined performance categories are presented in Table A-2 (Appendix A). The implementation of a graded 
approach, considering the relative hazards and consequences related to failure of a facility, is the primary difference between the DOE and NRC seismic design criteria.

\subsection{COMPARISON OF NRC AND DOE SEISMIC DESIGN METHODOLOGIES}

The DOE structural design methodology that would be employed for a facility such as the CSB originates from the Lawrence Livermore National Laboratory UCRL-15910, Design and Evaluation Guidelines for DOE Facilities Subjected to Natural Phenomena Hazards Design and Evaluation Criteria for DOE facilities (UCRL 1990). These criteria ensure ductile design by specifying the minimum ductility requirements. It then allows credit to be taken for higher damping values and an inelastic reduction factor. This type of design has been found to be very resilient to dynamic loading that occurs during seismic events.

The above approach to structural design is in contrast to that prescribed by the NRC Standard Review Plan (NRC 1989), which requires structures to remain primarily elastic during design basis events. This methodology results in very strong, robust structures and is most appropriate for reactor containments because the worst case accident loading usually stems from overpressure events rather than from seismic events. 


\subsection{APPLICATION OF SEISMIC DESIGN CRITERIA TO THE CANISTER STORAGE BUILDING}

Application of DOE Order 5480.28 and its implementing standards provides a graded approach for developing a facility's seismic design requirements depending upon the performance category and performance goal that it is assigned. Thus, to compare designs developed under DOE and the NRC seismic design criteria, the type of facility and its hazards must be known. The CSB facility was selected as an example case application of the DOE and NRC seismic design criteria. The NRC seismic response spectra for the CSB are developed according to $10 \mathrm{CFR}$ 100, Appendix A requirements for a nuclear power plant. The objective of this discussion will be to develop the rationale for selection of the DOE NPH performance category. The NPH performance category and 10 CFR 100, Appendix A criteria form the basis for determining the seismic design response spectra presented in Section 4.0.

\subsection{PROCESS AND DESIGN DESCRIPTION}

Spent nuclear fuel from Hanford's plutonium production reactors is currently stored under water in two fuel storage basins in the $100 \mathrm{~K}$ area of the Hanford site. The fuel will be moved to interim dry storage in the CSB, located in the 200 East area of the site.

The CSB will be a concrete structure containing three below-grade storage vaults. The structure will be approximately 166 -feet wide by 181 -feet long and will be supported on a $52 / 3$-foot thick base mat. A five-foot thick operating deck will cover the storage vaults and the operating area will be covered by a 32 -foot high steel structure.

Operations at the fuel storage basins in the $100 \mathrm{~K}$ area will remove the fuel elements from the canisters in which they are currently packaged. The fuel elements will be cleaned of sludge and debris and packed in baskets. The baskets will then be placed in a multicanister overpack (MCO). Each MCO will hold approximately $5400 \mathrm{~kg}$ of fuel elements and large fuel pieces. A vacuum drying process will remove residual water, and the MCO atmosphere will be replaced with an inert cover gas before the MCOs are placed in casks for shipping to the CSB.

One of the CSB storage vaults will be used for the storage of the spent nuclear fuel. The CSB vault will contain 26-inch diameter steel tubes that extend from the floor to the operating deck. The MCOs will be stacked vertically in the tubes, two to a tube, and the storage tubes will be capped with concrete seal plugs. 


\subsection{PRELIMINARY SAFETY ANALYSES}

A Preliminary Safety Evaluation (PSE) (WHC 1995b) was performed to support the conceptual design of the CSB. The accident scenarios considered credible include the following:

1. An MCO overpressurization during staging. Overpressurization of the $\mathrm{MCO}$ is assumed to occur as a result of hydrogen buildup, rupturing the MCO rupture disk.

2. Dropping of an $\mathrm{MCO}$ into a storage tube. Human error or equipment failure is assumed to result in an MCO being dropped into a storage tube where another MCO is being stored. Both MCOs are assumed to fail, releasing their contents.

3. MCO failure during dry storage. It is assumed that passivation has been imperfect and that the fuel surface is available for oxidation. An unspecified event causes an opening to develop in the MCO canister that is large enough to allow air to pass between the inside and outside of the $\mathrm{MCO}$ with negligible friction losses, but small enough that the exchange of gases is dominated by the volume change in response to atmospheric pressure fluctuations in the tube.

The safety evaluation considered $\mathrm{MCO}$ inventories that included a five percent by weight loading of sludge. In the current process, the fuel material is cleaned and reracked before being packaged in the MCO canister. The accidents considered in the PSE were reevaluated based on the current process.

Preliminary analyses indicate acceptable offsite consequences in terms of the maximum exposed individual (MEI) throughout the entire range of accident frequencies. The MEI is defined as the radiological dose consequences received by an individual at the site boundary in the direction of the maximum plume release. Exposures to the total population surrounding the site from the site boundary out to 80 kilometers, in terms of increased cancer incidents, are well below the DOE safety goal for all frequencies.

The results of the accident analysis are illustrated in Table 1. 
Table 1. Accident Analyses Results

\begin{tabular}{|l|c|c|c|}
\hline \multicolumn{1}{|c|}{ Accident } & $\begin{array}{c}\text { Total Fual } \\
\text { Material Released }\end{array}$ & $\begin{array}{c}\text { Offsite MEI } \\
\text { Consequences }\end{array}$ & $\begin{array}{l}\text { Average Annual Population } \\
\text { Exposure (Increased cancer } \\
\text { incidents) }\end{array}$ \\
\hline $\begin{array}{l}\text { An MCO overpressurization } \\
\text { during staging. }\end{array}$ & $7.9 \mathrm{~g}$ & $.02 \mathrm{rem}$ & $2 \times 10^{-10}$ \\
\hline $\begin{array}{l}\text { Dropping of an MCO into a } \\
\text { storage tube. }\end{array}$ & $14 \mathrm{~g}$ & $.05 \mathrm{rem}$ & $4 \times 10^{-10}$ \\
\hline $\begin{array}{l}\text { MCO failure during dry } \\
\text { storage. }\end{array}$ & $0.037 \mathrm{mg}$ & negligible & $1 \times 10^{-15}$ \\
\hline
\end{tabular}

In addition, a very conservative bounding accident was considered in the Hazard Category Analysis for the CSB (WHC 1995c). Based on the results of the Hazards Category Analysis, the CSB has been initially classified as a Hazards Category 2 facility. The postulated accident assumed the total collapse of the CSB structure, as well as failure of all 390 MCOs, releasing their contents. The assumptions used in this analysis included:

1. The remaining respirable particulate material (i.e., the material assumed to be at risk of release) in the MCO after treatment and before shipping was taken to be a maximum of $6.5 \mathrm{~kg}$. This $6.5 \mathrm{~kg}$ value is conservatively assumed to be the average value present for long-term storage.

2. The isotopic content of the particulate is assumed to be the same as the fuel.

3. The release from the MCOs was a re-suspension over a 24-hour period of the fine particulate material.

4. It was also assumed that $1 \%$ of the MCOs (4) had not been adequately dried, or adequately vented, and contained hydrogen gas buildup from radiolysis and corrosion, resulting in a sudden venting of particulate material (resulting in a total of $13.0 \mathrm{~kg}$ of material at risk for each container).

5. The fuel elements and large fuel pieces are excluded from the inventory of material that may be released. 
6. No mechanism could be identified that would result in a significant temperature increase-fuel pieces larger than $1 \mathrm{~cm}$ would not reach temperatures sufficient for self-sustained ignition.

The results of these analyses are shown in Table 2.

Offsite MEI consequences greater than 0.5 rem require a Safety Class (SC) 1 confinement barrier to preclude the release of significant quantities of material per the Westinghouse Hanford Company Safety Analysis Manual, Safety Class Criteria (WHC 1992), which is consistent with DOE Order 6430.1A, General Design Criteria.

Table 2. Conservative Analyses Results

\begin{tabular}{|l|c|c|c|c|}
\hline \multirow{1}{*}{ Accident } & $\begin{array}{c}\text { Total Fuel Material } \\
\text { Released }\end{array}$ & $\begin{array}{c}\text { Average Annual } \\
\text { Population Exposure } \\
\text { (Increased cancer } \\
\text { incidents) }\end{array}$ \\
\hline $\begin{array}{l}\text { Bounding accident } \\
\text { (complete facility } \\
\text { failure). }\end{array}$ & $2,460 \mathrm{~g}$ & $1.7 \mathrm{rem}$ & $6 \times 10^{-8}$ \\
\hline
\end{tabular}

Per NRC 10 CFR 72, the MCO performs a function that is important to safety-namely, the primary confinement against radioactive material releases. The SNF Project position is to apply SC-1 design criteria to those structures, systems, and components that would be identified as important to safety by 10 CFR 72 . Therefore, the MCO will be designed to SC-1 design requirements. The storage tube provides a secondary confinement boundary and will also be designed to $\mathrm{SC}-1$ design requirements as a means of providing defense-in-depth. ${ }^{2}$

To provide further defense-in-depth and preclude common cause failure of the MCOs (assumed in the bounding accident), the concrete vault substructure and operating deck will also be designed to SC-1 design requirements. Designing these structures to SC-1 requirements will ensure that no scenario with consequences even approaching the bounding accident in the hazard categorization document will occur.

Defense-in-depth is an approach to facility safety that builds in layers of defense against release of materials so that no one layer by itself, no matter how good, is completely relied upon (DOE 1994a). 


\subsection{SAFETY CLASS AND PERFORMANCE CATEGORY CORRELATION}

DOE Orders 5480.23, Nuclear Facility Safety Analysis Reports, and DOE 5480.22, Technical Safety Requirements, and their associated standards rely on the safety classification of structures, systems, and components to grade requirements. DOE Order 5480.28, Natural Phenomena Hazards Mitigation, and its standards use performance categories to provide NPH design requirements within the graded approach. The safety classification process also uses a graded approach. The consequence limits and other criteria used to classify structures, systems, and components are defined in the Westinghouse Hanford Company Safety Analysis Manual (WHC 1992) and include radiological and toxicological criteria. The correlation of NPH performance categories and safety classification leads to a unified graded approach.

Qualitative correlation of the NPH performance categories and safety classification is provided by matching the concepts and terminology of the NPH performance categories to the concepts and terminology used in the safety classification process (Webb 1994). Quantitative correlation is achieved by comparing safety classification limits to performance category numerical values.

Because of their importance to safety, the MCOs are a Safety Class 1 confinement barrier. Based on the safety analysis and principles of defense-in-depth, the storage tubes, operating deck, and vault substructure are also categorized as Safety Class 1 . Using the WHC correlation between their safety classification process and performance categories (Webb 1994), the vault substructure, operating deck, MCOs, and storage tubes will be designed to NPH PC-3 requirements. 


\subsection{EAST AREA CSB SITE SEISMIC RESPONSE}

\subsection{PERFORMANCE CATEGORY 3 SEISMIC DESIGN RESPONSE SPECTRA}

The CSB (including the MCOs, storage tubes, vault substructure and operating deck) has been classified as NPH Performance Category 3 and will be designed to PC-3 requirements. The PC-3 is anchored at the $5 \times 10^{-4}$ seismic hazards exceedance probability (2000-year return period) for ground motion (see Table A-2, Appendix A). Based on the probabilistic seismic hazard assessment of the Hanford site (Geomatrix 1994a), the 2000year peak horizontal ground motion is about $0.2 \mathrm{~g}$. at the CSB site.

The 5\% damped, equal-hazard, PC-3 horizontal and vertical response spectra for the CSB site are shown in Figures 1 and 2 respectively (Geomatrix 1994b). An equal-hazard response spectrum is produced by plotting the spectral acceleration at multiple frequencies to define the spectral shape for the site. The vertical spectrum (Figure 2) was developed from the horizontal spectrum using draft American Society of Civil Engineers Standard Number 4, Seismic Analysis of Safety Related Nuclear Structures (ASCE 1995). The ASCE draft standard calls for near-field (distances less than $15 \mathrm{~km}$ ) vertical motions to be equal to the horizontal for frequencies above $5 \mathrm{~Hz}$ and two-thirds of horizontal for frequencies below $3 \mathrm{~Hz}$.

\subsection{NRC APPENDIX A-TYPE GROUND MOTION}

Response spectra were also developed to meet the intent of a 10 CFR 100, Appendix A-type assessment. The seismic sources, structures and magnitudes, used in this assessment were the same as those used in the NRC power-reactor licensing of the Washington Public Power Supply System WNP-2, also on the Hanford site. The sources that control the seismic design response spectra at the CSB location are Gable Mountain and the Rattlesnake-Wallula alignment. Gable Mountain is $5.5 \mathrm{~km}$ from the site with a magnitude of $5 \pm 1 / 2$ and the Rattlesnake-Wallula alignment is $14 \mathrm{~km}$ from the site with a magnitude of $61 / 2$. The site specific spectra for these two sources are enveloped by the "estimated NRC equivalent" shown in Figure 1. The response spectrum was developed using more recently developed attenuation relationships and other NRC licensing practices such as $84 \%$ ground motion and spectral amplification.

The horizontal acceleration response spectrum is anchored to a peak ground acceleration of $0.49 \mathrm{~g}$ and the vertical response spectrum (Figure 2 ) is equal to the horizontal until $5 \mathrm{~Hz}$, where it decreased to two-thirds of the horizontal spectrum. 


\subsection{CURRENT CANISTER STORAGE BUILDING SEISMIC DESIGN}

The SNF Project has selected the partially completed Canister Storage Building, located in the 200 East area of the Hanford site, as a candidate for interim storage of the $\mathrm{K}$ Basins fuel. The CSB was originally designed for the Hanford Waste Vitrification Project (HWVP). Construction of the base mat and part of the east and north walls were completed prior to termination of the HWVP in 1992. The option to use the CSB offers significant cost and schedule benefits for the project.

The current CSB was designed to a Newmark and Hall median horizontal seismic design spectra anchored at $0.35 \mathrm{~g}$ (Newmark 1978). The design was developed in anticipation of the draft DOE-STD-1020 (DOE 1994b) and the draft seismic hazard assessment of the Hanford site (Geomatrix 1994a). The return period for $0.35 \mathrm{~g}$ is about 8,000 years (Geomatrix 1994a). The 5\% damped, equal-hazard, horizontal response spectra for the current CSB is included in Figure 1. The vertical response spectrum is two-thirds the horizontal and is included in Figure 2. A comparison of the current CSB seismic design response spectra is readily made with the PC-3 and NRC 10 CFR 100, Appendix A, horizontal and vertical design response spectra by referencing Figures 1 and 2 , respectively.

The response spectra illustrate that the current CSB seismic design response spectra conservatively envelopes the PC-3 response spectra over the entire range of frequencies for both vertical and horizontal response spectra. In addition, the CSB design methodology will be implemented in a manner that envelops the requirements of DOE Order 5480.28 and DOE-STD-1020. 
Figure 1. Horizontal Response Spectra for the 200 Area Canister Storage Building Site.

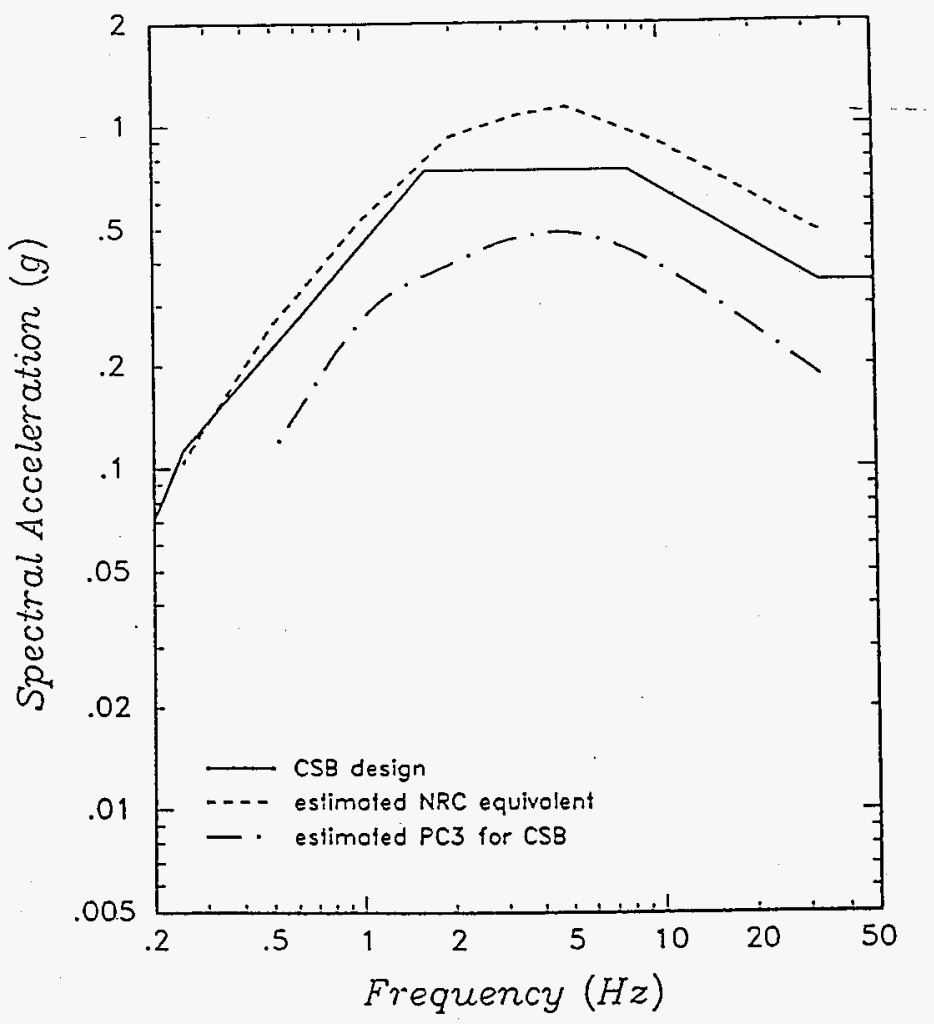

horizoniol 
Figure 2. Vertical Response Spectra for the 200 Area Canister Storage Building Site.

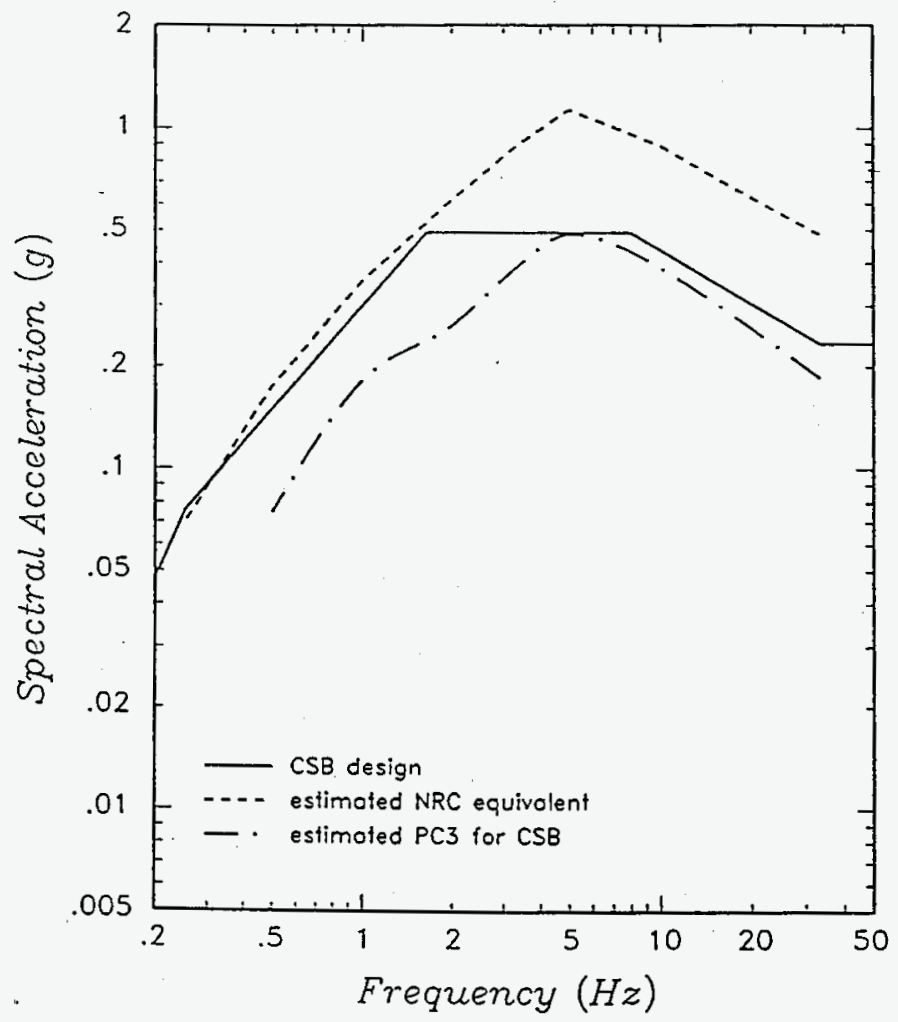

verticol 


\subsection{SAFETY DISCUSSION}

The objective of this discussion is to compare designs developed using the DOE and NRC seismic design criteria to support selection of the appropriate criteria for the SNF Project new facilities. This is accomplished by using the requirements of a spent fuel storage facility, like the CSB, as an example case application of the DOE and NRC seismic design criteria. The resulting designs produced using the DOE and NRC criteria are qualitatively compared, along with seismic risks, and other SNF Project considerations (e.g., cost and schedule) that impact selection of the seismic design criteria.

\subsection{STRUCTURAL DESIGNS}

A comparison of the structural designs produced by implementing the DOE and NRC seismic design criteria for the CSB demonstrates that the NRC criteria produces a design that is substantially more robust than a CSB designed to the DOE PC-3 requirements. This results from applying the seismic design response spectra for the CSB as discussed in Section 4.0. The NRC seismic design response spectra that would be applied to the Hanford 200 East area (the location of the CSB) is estimated to be about $0.49 \mathrm{~g}$. For the DOE Performance Category 3, the seismic design response spectra is anchored at approximately $0.2 \mathrm{~g}$. Thus, the NRC and DOE seismic design criteria do not produce designs that are equivalent.

\subsection{SEISMIC SAFETY RISKS}

The NRC seismic design criteria of 10 CFR 100, Appendix A, were developed to provide an adequate a level of seismic safety for nuclear reactor facilities. These same criteria are required for the design of NRC-licensed spent fuel storage facilities. Since there are few NRC-licensed facilities comparable to the SNF Project's CSB, the seismic safety risks associated with NRC-licensed nuclear reactor facilities were compared to those of the CSB. The comparison demonstrates that use of the DOE seismic design criteria results in a design that achieves seismic safety risks comparable to NRC-licensed facilities.

Total risk from a seismic event is defined as the mathematical product of the probability of occurrence times the consequences. Comparing seismic safety risks between DOE and NRC nuclear reactor facilities requires that the probability and consequences of a seismic event that results in the exceedance of acceptable facility performance be determined. The total radionuclide inventory (radionuclides important to health) of the spent nuclear fuel to be stored in the CSB is much smaller than the comparable radionuclide inventory for a nuclear power plant. ${ }^{3}$ Of particular importance for the CSB spent fuel is the reduced inventory of noble gases and short-lived fission products. The radiological dose

3 Comparative radionuclide inventory data is from the Diablo Canyon nuclear power plant Final Safety Analysis Report. 
consequences to the public from the potential release of radionuclides is directly proportional to the total radionuclide inventory at risk. The radiological dose consequences to the public from the potential release of radionuclides from a reactor facility is estimated to be approximately two orders of magnitude greater than the radiological dose consequences from the potential release of radionuclides from the spent nuclear fuel stored in the CSB.

The release mechanism assumed for a nuclear reactor is core damage resulting from a seismic event that exceeds the design basis. For the CSB, the postulated release mechanism is total collapse of the structure and MCOs following a seismic event that exceeds the design basis. Evaluating the energetics available to release the radionuclide content, it is evident that the energetics in a reactor facility are much larger than the energetics that are available to release the radionuclide content from the spent nuclear fuel stored in the CSB. Consequently, both the likelihood of a radionuclide release and the quantity of radionuclides available for release would be greater from a reactor facility than from the spent nuclear fuel stored in the CSB.

For nuclear power plants, the mean annual seismic core damage frequencies are presented in Table A-1 (Appendix A) from published probabilistic risk assessments (PRAs) for seven plants, based on utility hazard estimates. The annual probabilities of seismically induced core damage ranged from about $3 \times 10^{-6}$ to $5 \times 10^{-5}$ per year (assumed equivalent to the performance goal, from Table A-2). Because the potential radiological dose consequences are two orders of magnitude larger for a nuclear reactor facility than for the CSB, to achieve comparable seismic safety, a higher probability of a radiological release as a result of a seismic event would be acceptable for the CSB (that is, a higher performance goal of $5 \times 10^{-3}$ per year or less).

Based on DOE Order 5480.28, Natural Phenomena Hazards Mitigation, a nuclear reactor facility would be assigned a performance category of PC- $4,{ }^{4}$ commensurate with the performance goal of an annual probability of seismic core damage of $1 \times 10^{5}$ per year. Using the same logic, the CSB could be assigned a performance category of PC-2 (associated with a performance goal of $5 \times 10^{4}$ per year). However, DOE Order 5480.28 and its implementation standards, requires that a Hazard Category 2 facility (with Safety Class 1 structures, systems, and components similar to the CSB) be designed to the requirements of PC-3. The performance category of PC-3 will be used for the MCOs, storage tubes, and the storage vault substructure as a means of providing defense-in-depth and added protection for the worker and the environment.

Calculating total seismic risks, the CSB designed to Performance Category 2 would provide a level of risk from seismic events that is nearly the same order of magnitude of risk from NRC-licensed nuclear power plants (Table A-2). The CSB designed to PC-3 provides a design that is approximately one order of magnitude lower ( 3 to 50 times lower) than the PC2 facility and that of typical nuclear reactor facilities. Although these figures represent an estimated range rather than precise calculations of risk, they demonstrate that the CSB designed to DOE seismic design criteria provides an acceptable level of nuclear safety and a

Performance Category 4 only strictly applies to DOE reactors. 
level of seismic protection that is equivalent to or better than that for a nuclear reactor facility. A comparison of NRC and DOE safety requirements supports the determination that the CSB, designed to PC-3, meets or exceeds the applicable safety requirements. Table 3 provides a summary of the comparison of important NRC and DOE safety items.

The current CSB, designed to $0.35 \mathrm{~g}$ seismic response spectra, achieves design requirements for seismic safety that exceed the DOE PC-3 criteria as discussed in Section 4.0. The current CSB design achieves a performance goal that is estimated to be between that required for a PC-3 and a PC-4 facility, at about $5 \times 10^{-5}$ (from Table A-2). Calculating the total seismic risk for the current CSB results in a design that is more than one order of magnitude lower in risk as compared to an NRC-licensed nuclear reactor facility.

In summary, the seismic design criteria that applies to NRC-licensed spent fuel storage facilities were developed to provide an adequate level of seismic safety for NRC nuclear reactor facilities. Considering the CSB, the potential consequences from seismically induced accidents are estimated to be two orders of magnitude less severe than those from a commercial nuclear reactor facility. Thus, applying the NRC seismic design criteria for a spent fuel storage facility to the CSB results in a design that achieves significantly higher levels of safety than that required for a nuclear reactor facility. Using the DOE graded approach, however, provides an appropriate level of safety based upon consideration of the facility's hazard potential. For the CSB, the DOE seismic design criteria provides a design that is adequately safe and exhibits seismic safety risks equivalent to or better than NRClicensed nuclear reactor facilities. 
Table 3. Comparison of Important Safety Items

\begin{tabular}{|l|l|l|}
\hline \multicolumn{1}{|c|}{ Iten } & \multicolumn{1}{|c|}{ NRC (Reactor) } & DOE (CSB) PC-3 Criteria \\
\hline \hline Nuclear Safety Policy & Equivalent & Equivalent \\
\hline Radionuclide Source & $-10^{8} \mathrm{Ci}$ (see Table A-1) & $\sim 10^{6} \mathrm{Ci}$ (see Table A-1) \\
\hline $\begin{array}{l}\text { Energetics; } \\
\text { High pressure } \\
\text { High temperature }\end{array}$ & $\begin{array}{l}\text { Very energetic; } \\
\text { Steam } \\
\text { Pressure } \\
\text { Temperature }\end{array}$ & $\begin{array}{l}\text { Less energetic; } \\
\text { No steam } \\
\text { Low pressure } \\
\text { Low temperature }\end{array}$ \\
\hline $\begin{array}{l}\text { Potential radiological dose } \\
\text { consequences }\end{array}$ & & $\begin{array}{l}\sim 10^{-2} \text { less than an NRC } \\
\text { reactor facility }\end{array}$ \\
\hline $\begin{array}{l}\text { Annual probability of } \\
\text { exceeding unacceptable } \\
\text { performance from a seismic } \\
\text { event }\end{array}$ & $\sim 10^{-5}$ per yr & $\begin{array}{l}\sim 10 \text { times larger for } \\
\text { comparable risk ( } ~ 10^{-4} \text { per } \\
\text { yr) }\end{array}$ \\
\hline $\begin{array}{l}\text { DOE NPH Performance } \\
\text { Category }\end{array}$ & PC-4 & $\begin{array}{l}\text { Could be as low as PC-2 } \\
\text { (will use PC-3) }\end{array}$ \\
\hline
\end{tabular}

\subsection{QUALITATIVE EFFECTS FROM AN NRC DESIGN EARTHQUAKE}

This section describes the effects of a $0.52 \mathrm{~g}$ horizontal ground acceleration event on a completed CSB that was designed for a $0.35 \mathrm{~g}$ horizontal acceleration (see figures 1 and 2), which is a $50 \%$ greater loading than the design.

As noted in Section 2.4.3 of the DOE Standard, DOE-STD-1020-94 (DOE 1994b), the basic intention of the seismic evaluation and acceptance criteria for PC-3 is to achieve less than a $10 \%$ probability of unacceptable performance for a structure, system, or component subjected to a scaled ground motion equal to 1.5 times the Design Basis Earthquake ground motion. Furthermore, Table C-2 of DOE-STD-1020-94 provides the following qualitative description of acceptable performance for the PC-3 category:

1. Concrete barriers can be cracked, but cracks should be small enough to maintain pressure differential with normal heating, ventilation and air conditioning (HVAC) systems. Cracks should not be expected to exceed $1 / 8$ of an inch. 
2. Metal liners and metal pressure-retaining components should remain leak-tight.

3. Components should remain anchored in place and be functional.

4. Visible local damage, but permanent distortion will not be immediately apparent to the naked eye.

The functions of the structure, including spent fuel cooling, should remain intact. Any structure, system, or component designed to the seismic evaluation and acceptance criteria for PC-3 in DOE-STD-1020-94 and for an acceleration response spectrum anchored at a peak horizontal acceleration of $0.35 \mathrm{~g}$, can be expected to have less than a $10 \%$ probability of suffering damage greater than that described above for a similar response spectra anchored at a $0.52 \mathrm{~g}$ peak horizontal acceleration ground motion.

\subsection{SNF PROJECT CONSIDERATIONS}

Using the NRC seismic design criteria of 10 CFR 100, Appendix A would require that the design of the CSB be upgraded from the PC-3 response spectra at approximately $0.2 \mathrm{~g}$ to $0.49 \mathrm{~g}$ response spectra. This would add significant unnecessary costs to develop an even more robust facility, when the PC- 3 requirement provides a more than adequate level of seismic protection. Thus, using the graded approach developed under the DOE seismic design criteria provides more cost effective designs for the SNF Project.

The impact to the SNF Project of upgrading the existing CSB structure to withstand 10 CFR 100, Appendix A level ground motions is estimated by the CSB designer to require a six-month slippage of the schedule. This slippage would extend beyond the December 1997 original start date for initiating fuel removal from the K Basins. A six-month schedule slippage would require the continued staffing of the K Basins and the SNF Project, amounting to additional project costs of approximately $\$ 21$ million for the $\mathrm{K}$ Basins and $\$ 4$ million for the project staff. This, along with the $\$ 3.5$ million direct design and construction costs, brings the total impact of the upgrade to approximately $\$ 29$ million.

The spent fuel in the $\mathrm{K}$ Basins is stored under water in a facility designed and constructed in the early $1950 \mathrm{~s}$. The $\mathrm{K}$ Basins are perceived by the public to be an unacceptable storage facility, which does not provide sufficient protection from the hazards presented by the fuel. That facility has the same likelihood of experiencing a seismic event of a given ground motion as does the CSB. The CSB is designed to withstand ground motions from a seismic event that produces greater ground motion $(0.35 \mathrm{~g})$ than any facility at the Hanford site. Other DOE facilities, including the K Basins, are designed to withstand $0.2 \mathrm{~g}$ or even less. The likelihood of damage to the $\mathrm{K}$ Basins from an event generating ground motions as high as $0.35 \mathrm{~g}$ is much greater than that of damage to the CSB.

The result of damage to the $K$ Basins could be greater than similar damage to the CSB because of the defense-in-depth designed into the CSB fuel storage. Once the fuel has 
been moved into the CSB, it will have been: (1) moved away from the river to prevent the effects of contamination reaching the river or the water table; (2) dried to stop the continuing corrosion that is producing radioactive particulates that can be spread following any release; (3) cleaned to remove the corrosion products from the past storage as much as possible; (4) conditioned to reduce the effect of air interaction with the fuel following an event; and (5) doubly contained (MCOs and storage tubes) to preclude air reaching and reacting with the fuel during an event.

The $\mathrm{K}$ Basins have none of these features that reduce the effects from an event. Moving the spent fuel away from the $\mathrm{K}$ Basins into the CSB will significantly reduce the risk related to the storage of the fuel. A comparison of the seismic safety risk assumed at the $\mathrm{K}$ Basins during the six month schedule delay, to the risk reduction achieved by increasing the CSB seismic design criteria from 0.35 response spectra to 0.49 response spectra, shows that the risks are of the same order of magnitude. Furthermore, the $\mathrm{K}$ Basins seismic risk represents only a portion of the total risk assumed during the six month delay. Consideration of risks based on other initiating factors would tend to increase the risk impact of delaying fuel removal from $\mathrm{K}$ Basins. Also, the consequences from design basis seismic events at the CSB are likely to be lower than at the K Basins, due to the defense-in-depth designed into the CSB. These factors tend to diminish any risk improvement that would be gained from the redesign of the CSB to the 0.49 response spectra.

\subsection{SELECTION OF SNF PROJECT SEISMIC DESIGN CRITERIA}

The SNF Project recommends using the seismic design criteria of DOE Order 5480.28. Designs produced using the DOE criteria are not equivalent to designs produced using the NRC criteria; however, the DOE Order and its implementation standards produce a design that is safe and provides a level of seismic risk protection comparable to that of NRClicensed reactor facilities. In the event that seismic activity the size of an NRC earthquake occurs, the design conservatism built into the CSB provides an acceptable level of protection against damage to the facility. Furthermore, the use of DOE seismic design criteria supports the SNF Project with regard to risk mitigation at the $\mathrm{K}$ Basins and the project cost and schedule considerations. 


\subsection{CONCLUSION}

The DOE Regulatory Policy for nuclear safety of the SNF Project's new facilities is being applied to the design and construction of the Project's new processes and facilities. This policy states ". . . that the K Basin Spent Nuclear Fuel Project will achieve nuclear safety equivalency to comparable Nuclear Regulatory Commission-licensed facilities." The policy objectives are "to achieve in the design and construction of new SNF Project facilities a level of nuclear safety comparable to that of NRC-licensed commercial nuclear facilities," and "to achieve a set of requirements that are technically defensible and cost effective."

This paper has considered the application of the seismic design requirements applicable to the SNF Project with regard to DOE's Regulatory Policy. After considering the differences in the DOE and NRC approaches with regard to seismic design criteria, the SNF Project concludes that the DOE seismic design criteria established in DOE Order 5480.28 , Natural Phenomena Hazards Mitigation results in designs that are safe, costeffective, and consistent with the intent of DOE's policy. The Regulatory Policy and the underlying objectives are met by the use of the DOE Order 5480.28 and the resulting PC-3 seismic response spectrum anchored at approximately $0.2 \mathrm{~g}$ for new SNF Project processes and facilities.

Furthermore, the current design criteria of the CSB, using a more conservative response spectra $(0.35 \mathrm{~g})$, provides an even greater level of safety than that provided by the use of a PC-3 response spectra for the SNF Project. 


\subsection{REFERENCES}

ASCE, 1995, Seismic Analysis of Safety Related Nuclear Structures, American Society of Civil Engineers, Standard Number 4.

Bernero, R., 1995, Basis for NRC Seismic Design Requirements for Spent Fuel Storage, (letter to R. Holt, U.S. Department of Energy, Richland Operations Office, September 30), Washington, D.C.

Bergsman, K. H., et al., 1995, K Basins Environmental Impact Statement Technical Input. WHC-SD-SNF-TI-013, Rev. A, Appendix A, July, Westinghouse Hanford Company, Richland, Washington.

DOE, 1992, Natural Phenomena Hazards Performance Categorization Criteria for Structures, Systems, and Components, DOE-STD-1021-92, U.S. Department of Energy, Washington, D.C.

DOE, 1994a, Preparation Guide for U.S. Department of Energy Nonreactor Nuclear Facility Safety Analysis Reports, DOE-STD-3009-94, U.S. Department of Energy, Washington, D.C.

DOE, 1994b, Natural Phenomena Hazards Design and Evaluation Criteria for Department of Energy Facilities, DOE-STD-1020-94, U.S. Department of Energy, Washington, D.C.

DOE, 1995, K Basins Spent Nuclear Fuel Project - Regulatory Policy, August, U.S. Department of Energy, Washington, D.C.

DOE Order 5480.22, Technical Safety Requirements, U.S. Department of Energy, Washington, D.C.

DOE Order 5480.23, Nuclear Facility Safety Analysis Reports, U.S. Department of Energy, Washington, D.C.

DOE Order 5480.28, Natural Phenomena Hazards Mitigation, U.S. Department of Energy, Washington, D.C.

DOE Order 6430.1A, General Design Criteria, U.S. Department of Energy, Washington, D.C.

Geomatrix, 1994a, Probabilistic Seismic Hazard Analysis, DOE Hanford Site, Washington, WHC-SD-W236A-TI-002, report prepared by Geomatrix Consultants for Westinghouse Hanford Company, Richland, Washington. 
Geomatrix, 1994b, Seismic Design Spectra 200 West and East Areas, DOE Hanford Site, Washington, WHC-SD-W236A-TI-016, report prepared by Geomatrix Consultants for Westinghouse Hanford Company, Richland, Washington.

Nelson, T. A., Murray, R., Short, S. A. And Kennedy, R. P., 1992, Seismic Design Strategy for New Production Reactors (NPR), UCRL-ID-110126, Lawrence Livermore National Laboratory, Livermore, California.

Newmark, N. M. and W. J. Hall, 1978, Development of Criteria for Seismic Review of Selected Nuclear Power Plants, NUREG/CR-0098, U.S. Nuclear Regulatory Commission, Washington, D.C.

NRC, 1989, Standard Review Plan, U.S. Nuclear Regulatory Commission, Washington, D.C.

UCRL, 1990, Design and Evaluation Guidelines for DOE Facilities Subjected to Natural Phenomena Hazards Design and Evaluation Criteria for DOE Facilities, UCRL15910, Lawrence Livermore National Laboratory, Livermore, California.

Webb, A. B. and Conrads, T. J., 1994, Proposed Correlation of DOE Safety Classes, Performance Categories, and Design Requirements, WHC-SD-GN-RD-30011, Westinghouse Hanford Company, Richland, Washington.

WHC, 1992, Westinghouse Hanford Company Safety Analysis Manual, WHC-CM-4-46, Westinghouse Hanford Company, Richland, Washington.

WHC, 1994, Spent Nuclear Fuel Project Recommended Path Forward, WHC-EP-0830, Rev. 0, Volumes I and II, Westinghouse Hanford Company, Richland, Washington.

WHC, 1995a, Hanford Spent Nuclear Fuel Project Integrated Process Strategy for K Basins Fuel, WHC-SD-SNF-SP-005, Rev. 0, Westinghouse Hanford Company, Richland, Washington.

WHC, 1995b, Spent Nuclear Fuel Path Forward Preliminary Safety Evaluation, WHC-SD-SNF-PSE-002, Rev. 0, Westinghouse Hanford Company, Richland, Washington.

WHC, 1995c, Hazard Category Analysis for the Canister Storage Building, WHC-SD-SNF-HC-007, Rev. 0, Westinghouse Hanford Company, Richland, Washington. 


\section{APPENDIX A}

Table A-1. Comparison of Mean Annual Seismic-Induced Core Damage Frequencies From Past Reactor Probabilistic Risk Assessments

\begin{tabular}{||l|c|}
\hline \multicolumn{1}{|l|}{ Power Reactor } & Mean Annual Core Damage Frequency $\left(1 / \mathrm{yr}_{\mathrm{r}}\right.$ \\
\hline Zion & $5.7 \times 10^{-6}$ \\
\hline Indian Point 2 & $4.8 \times 10^{-5}$ \\
\hline Indian Point 3 & $3.1 \times 10^{-6}$ \\
\hline Limerick & $5.8 \times 10^{-6}$ \\
\hline Millstone 3 & $8.9 \times 10^{-6}$ \\
\hline Seabrook & $2.3 \times 10^{-5}$ \\
\hline Shoreham & $2.6 \times 10^{-6}$ \\
\hline \hline
\end{tabular}

(Nelson 1992)

Table A-2. Comparison of Natural Phenomena Hazards

Performance Goals and Performance Categories

\begin{tabular}{|c|c|c|c|c|}
\hline$P_{\mathrm{P}}(1 /$ year $)$ & $\begin{array}{c}\text { Performance } \\
\text { Category }\end{array}$ & $\mathrm{P}_{\mathrm{H}}(1 /$ year $)$ & Return Period $(\mathrm{yr})$ & $\begin{array}{c}\text { Risk Reduction Factor } \\
\left(\mathrm{R}_{\mathrm{F}}=\mathrm{P}_{\mathrm{F}} / \mathrm{P}_{\mathrm{P}}\right.\end{array}$ \\
\hline $1 \times 10^{-3}$ & $\mathrm{PC}-1$ & $2 \times 10^{-3}$ & 500 & 2 \\
\hline $5 \times 10^{-4}$ & $\mathrm{PC}-2$ & $1 \times 10^{-3}$ & 1,000 & 2 \\
\hline $1 \times 10^{-4}$ & $\mathrm{PC}-3$ & $5 \times 10^{-4}$ & 2,000 & 5 \\
\hline $1 \times 10^{-5}$ & $\mathrm{PC}-4$ & $1 \times 10^{-4}$ & 10,000 & 10 \\
\hline
\end{tabular}

$\mathrm{P}_{\mathrm{F}}=$ Performance Goal $=$ Annual probability of exceedance of acceptable behavior limits

$\mathrm{P}_{\mathrm{H}}=$ Seismic hazards exceedance probability;

Return Period $=1 / \mathrm{P}_{\mathrm{H}}$

(DOE Order 5480.28 and DOE 1994b) 


\section{DISTRIBUTION SHEET}

\begin{tabular}{|c|c|c|c|c|c|}
\hline \multirow{2}{*}{$\begin{array}{l}\text { To } \\
\text { Distribution }\end{array}$} & \multirow{2}{*}{\multicolumn{3}{|c|}{$\begin{array}{l}\text { From } \\
\text { SNF Project Regulatory } \\
\text { Programs }\end{array}$}} & \multicolumn{2}{|c|}{ Page 1 of 1} \\
\hline & & & & \multicolumn{2}{|c|}{ Date $02 / 12 / 96$} \\
\hline \multirow{2}{*}{\multicolumn{4}{|c|}{$\begin{array}{l}\text { Project TitleMork Order } \\
\text { WHC-SD-SNF-DB-004, Rel } \\
\text { Criteria - NRC Equival }\end{array}$}} & \multicolumn{2}{|c|}{ EOFNO. 630480} \\
\hline & & & & \multicolumn{2}{|c|}{ ECN No. ItA W } \\
\hline Name & MSIN & $\begin{array}{l}\text { Text } \\
\text { With All } \\
\text { Attach. }\end{array}$ & Text Only & $\begin{array}{l}\text { Attach./ } \\
\text { Appendix } \\
\text { Only }\end{array}$ & $\begin{array}{c}\text { EDT/ECN } \\
\text { Only }\end{array}$ \\
\hline $\begin{array}{l}\text { KD Daschke } \\
\text { LJ Garvin } \\
\text { LH Goldmann } \\
\text { JJ Irwin } \\
\text { MK Mahaffey } \\
\text { CR Miska } \\
\text { GC Mooers } \\
\text { ED Sellers } \\
\text { DW Smith } \\
\text { KE Smith } \\
\text { CA Thompson } \\
\text { JE Turnbaugh } \\
\text { AM Zaman } \\
\text { SNF Project Files }\end{array}$ & $\begin{array}{l}\text { R3-85 } \\
\text { R3-85 } \\
\text { R3-86 } \\
\text { H0-33 } \\
\text { R3-85 } \\
\text { R3-86 } \\
\text { R3-11 } \\
\text { S7-41 } \\
\text { R3-11 } \\
\text { R3-85 } \\
\text { R3-85 } \\
\text { H6-21 } \\
\text { B1-10 } \\
\text { R3-11 }\end{array}$ & $\begin{array}{l}x \\
x \\
x \\
x \\
x \\
x \\
x \\
x \\
x \\
x \\
x \\
x \\
x \\
x\end{array}$ & & & \\
\hline
\end{tabular}

